\title{
Food Wasting Behaviours Questionnaire. A Test of a New Method and a Natural Experiment During the COVID-19 Pandemic
}

\author{
THIS IS A PREPRINT. THE MANUSCRIPT HAS NOT YET BEEN PEER-REVIEWED (ver. 23.04.22) \\ Michal Misiak ${ }^{1,4}$, Małgorzata Sobol $^{2}$, Łukasz Sakowski, Marta Kowal ${ }^{3}$, Aleksandra Jurczyk ${ }^{3}$, Lidia Wojtycka ${ }^{3}$ \\ ${ }^{1}$ IDN Being Human Lab, University of Wroclaw, ul. Dawida 1, 50-527 Wroclaw, Poland \\ ${ }^{2}$ Department of Psychology, University of Warsaw, u. Stawki 5/7, 00-183 Warsaw, Poland \\ ${ }^{3}$ Institute of Psychology, University of Wroclaw, ul. Dawida 1, 50-527 Wroclaw, Poland \\ ${ }^{4}$ Institute of Anthropology \& Museum Ethnography, University of Oxford, 51/53 Banbury Road, Oxford, OX2 6PE, \\ United Kingdom
}

\section{Author Note}

The studies were pre-registered (https://osf.io/6e7ku; https://osf.io/f7hs4) and the data are publicly available (https://osf.io/gcfra/files/).

Acknowledgements: We would like to thank Paulina Idziak, Marta Rokosz, and Michał Stefańczyk for their help with the recruitment of participants and valuable comments on the design of the studies.

This study was supported by National Science Center, Poland (2016/23/N/HS6/00849 to Michał Misiak). Michał Misiak was supported by the START scholarship of the Foundation for Polish Science (FNP), by the scholarship of the National Science Centre (2020/36/T/HS6/00256) and by the Scientific Excellence Incubator - Being Human.

\section{Author contributions}

All authors have approved the final article. Conceptualization: MM, MS; Methodology: MM, MS, ŁK, MK, AJ, LW; Formal analysis: MM; Investigation: MM, tS, MK, AJ, LW; Data Curation: MM; Writing - Original draft: MM; Writing - Review \& Editing: MM, MS, ŁK, MK, AJ, LW; Visualization: MM; Supervision: MM, Project Administration: MM, Funding Acquisition: MM. Declarations of interest: none.

Corresponding Author: Michal Misiak, IDN Being Human Lab, University of Wroclaw, ul. Dawida 1, 50-527 Wroclaw, Poland; michal.misiak@uwr.edu.pl 


\begin{abstract}
Measuring food wasting behaviour is challenging. Existing methods focus on the household level, which makes studying situational factors and individual differences associated with food wasting extremely difficult. To facilitate such research, we conducted a series of pre-registered studies and developed the Food Wasting Behaviours Questionnaire (FWBQ). As a result of our research programme, we found that behaviours associated with food wasting could be narrowed down to five distinctive basic categories: (1) discarding food because of its' unpalatability; (2) preventing food waste through buying only the necessities; (3) preventing food waste through planning; (4) preventing food waste through sharing; and (5) preventing food waste through feeding animals. The FWBQ allowed us to investigate the socioeconomic factors that influence food wasting behaviour, such as food insecurity. Furthermore, because we started our research programme before the pandemic, we were able to conduct a natural experiment and use FWBQ to observe that people changed their food wasting behaviour during the pandemic. Finally, we found that FWBQ allowed for predicting the amount of wasted meat, dairy, and bakery products. In summary, we have demonstrated the potential utility of the FWBQ, an inexpensive and easy-to-use method for predicting the factors and antecedents of food wasting behaviour.
\end{abstract}

Keywords: food waste, food wasting behaviour, COVID-19, pandemic, food insecurity 


\section{Food Wasting Behaviours Questionnaire. A Test of a New Method and a Natural Experiment During the COVID-19 Pandemic}

Consumer food wasting behaviour is a burning environmental and social problem-yet, we still do not fully understand how to prevent it (Principato, 2018; Quested et al., 2013). Neglecting this issue contributes to environmental damage, like deforestation (Houghton, 2012), water contamination (Chapagain \& James, 2013), and climate change (Melikoglu et al., 2013). This, in turn, negatively affects the lives of people all over the world (Intergovernmental Panel on Climate Change, 2018). The most prominent international organizations aim to minimize the negative impact of food wastage in line with the idea of sustainable development - the United Nations aims at halving per capita global household and retail level food waste by 2030 (United Nations, 2020). Following these goals, the European Commission calls for awareness campaigns to change consumer behaviour (European Commission, 2021). In industrialised countries, the biggest amount of food is wasted by direct consumers in their households (Parfitt et al., 2010). To prevent negative consequences, we need to understand the behaviours that make people discard their foods and the reasons that lead them to do it. Recent research reviews, published on the topic of household food waste, stress the importance of two categories playing a deciding role in shaping food wasting behaviours: individual and situational factors (Hebrok \& Boks, 2017; Porpino, 2016; Principato, 2018; Schanes et al., 2018). Although we have a fair idea of potential individual (e.g., psychological characteristics, age) and situational factors (e.g., household size, economic situation) affecting food wasting behaviours, we are unable to estimate and compare their impacts. The problem lays in a lack of tools for assessing consumer food wasting behaviours systematically.

Measuring food wastage is a challenge, not only on the global but also on the consumer level (Food and Agriculture Organization, 2019). According to the review by van Herpen and colleagues (2019), researchers lack a gold standard. They often use kitchen caddies, photo coding, or-less often-waste composition analysis. Employing these methods requires participants to put effort into measuring the food waste, sometimes throughout several days. This, in turn, increases the drop-out rate and questions data 
accuracy (van Herpen, van der Lans, et al., 2019). Although useful, these methods are complicated for the participants as well as time and resource-consuming for the researchers. This limits the possibility of employing them in large-scale research programmes. They also do not provide any information of proximate causes of food waste, like consumer behaviours - they rather assess their effects.

There are two categories of self-report questionnaires for assessing consumer food waste: questionnaires directly aimed at measuring the amount of wasted food (e.g., van Herpen, van Geffen, et al., 2019), and questionnaires assessing the frequency of behaviours that lead to food waste (e.g., Misiak et al., 2020).

The first category, although much less complicated and less expensive than direct observations, may result in biased estimates of the amount of wasted food due to underreporting caused by social desirability bias (van Herpen, van der Lans, et al., 2019) along with difficulty in recollecting the memories of the amount of wasted food (Jörissen et al., 2015). To improve the quality of direct self-reports, researchers have to pre-announce the survey several days before the actual study and specify detailed product categories to facilitate the recall (van Herpen, van Geffen, et al., 2019). Also, these types of measures assess the consumer food waste on a household level-these are not suitable to assess the amount of food waste produced by a single person, which limits the possibility of testing the hypotheses regarding individual factors (e.g., psychological), that may affect food wasting behaviours. The perspective of the individual person might be even more important in the future. Given the declining household sizes (Bradbury et al., 2014), an increased amount of people will be responsible for their personal wastage-in bigger households this responsibility is being shifted to others-in most cases, women (Shelton \& John, 1996). Furthermore, there is a rising popularity of initiatives, such as food sharing, that allows people to minimize their personal amount of food wastage through donating and exchanging foods (Schanes \& Stagl, 2019).

The second category of self-report food wasting methods provides no information on the actual amount of wasted food. It assesses the frequency of behaviours that lead to food wasting, like poor 
shopping, storing or managing habits (Schanes et al., 2018). This approach pinpoints the behaviours that could be addressed during informational campaigns or other interventions aimed at minimizing consumer food wasting behaviour (Schmidt \& Matthies, 2018). Moreover, it allows for identifying and testing individual factors underlying particular behaviours that lead to food waste-for example, moral attitudes may influence planning more strongly than shopping (Stefan et al., 2013). The untapped advantage of this approach lies in the possibility of assessing and comparing diverse types of behaviours leading to food waste. Thus, it allows for clarifying whether some individual and situational factors shape only specific food wasting behaviours, or whether these factors shape more than one category of behaviours. However, the current methods target only narrow groups of behaviours, which makes comparing them impossible (e.g., Misiak et al., 2020; Stancu et al., 2016; Stefan et al., 2013).

Recent conceptual models of consumer food waste highlight the importance of psychological and situational factors, which shape behaviours and influence the amounts of wasted food (Boulet et al., 2020; Roodhuyzen et al., 2017; Stancu et al., 2016). In his review, Porpino (2016) highlighted the key drivers. For example, he identified several psychological factors, namely, one's own identity, emotional responses to food waste or the knowledge on managing the leftovers; and situational factors, like caring for a pet and the size or composition of ones' family. Similarly, recent studies have accentuated the importance of routines (Romani et al., 2018), morality (Misiak et al., 2020), and cognitive processes (Nicholes et al., 2019) contributing to behaviours that increase consumer food waste. However, these studies used numerous methods for assessing various food wasting behaviours - this, in turn, hinders the possibility to quantitively synthesize the knowledge in meta-analyses and compare the power of factors that lead to certain categories of behaviours.

\subsection{Current Research}

This paper introduces the Food Wasting Behaviours Questionnaire (FWBQ) - a novel method for preliminary research on food wasting behaviours that allows for inexpensive and systematized studies. We pre-registered and conducted four studies in which we developed and tested the utility of the presented 
tool. We intended to resolve two problems with contemporary methods used to assess consumer food waste: (1) the lack of established categories of food wasting behaviours, (2) difficulties in assessing food waste-both for the participant and the researcher. In Studies $1 \mathrm{a}$ and $1 \mathrm{~b}$, we empirically developed a fivefactor questionnaire for measuring food wasting behaviours. In Study 2, we used the questionnaire to verify whether it allows predicting the amount of wasted meat, dairy, and bakery. Study 3 was conducted during the pandemic. Because we gathered data in 2019, before the pandemic started, we were able to monitor the within-subject change in peoples' food wasting behaviours. We evaluated the applicability of the questionnaire in measuring situational (the lockdown) and individual (food insecurity) conditions affecting food wasting behaviours.

The studies were conducted in accordance with the Declaration of Helsinki. Also, the Institutional Ethics Committee approved the studies. All the participants gave their informed consent to participate in the study.

\section{Study $1 a$ and $1 b$}

In Study $1 \mathrm{a}$ and $1 \mathrm{~b}$, we aimed at constructing a questionnaire suitable for assessing consumers' food wasting behaviours, through investigating the behaviours associated both with discarding edible foods and behaviours associated with preventing food spoilage. In Study 1a, we asked people to spontaneously list different behaviours that in their opinion cause food to be discarded and to generate a separate list of behaviours that prevent foods from being discarded. In Study 1b, we reformulated the proposed reasons into items and verified whether any common factors underlie these behaviours. We hypothesized that factor analysis would reveal behavioural categories similar to those included in Food Recovery Hierarchy (FRH) by the USA Environmental Protection Agency: source reduction, feeding hungry people, feeding animals, and composting (Environmental Protection Agency, 2015). The FRH includes an additional step: industrial uses, but it is unavailable for a regular consumer. This framework was previously used to describe the categories of behaviours associated with food wasting behaviours and because of that, we assumed that it is a good reference point to start with (Papargyropoulou et al., 2014). Results of 
Study $1 \mathrm{a}$ and $1 \mathrm{~b}$ allowed us to establish a five-factor questionnaire-Food Wasting Behaviours Questionnaire (FWBQ).

\subsection{Methods}

In Study 1a, we distributed the invitation to the online survey via social media. The participants listed the behaviours that, in their opinion, result in discarding edible food. Separately, they listed the behaviours that prevent food from being discarded. The sample consisted of 177 participants who listed 77 unique behaviours associated with food discarding and 73 unique behaviours associated with preventing food from being discarded. The complete list of behaviours is presented in Supplementary Material Table S1. The initial screening of participant's responses suggested that some of them did not list actual behaviours (i.e., having a larger fridge), some listed behaviours that are very unique and may not be exhibited frequently (i.e., discarding food after illness-related diet switch), and some of them listed behaviours specific only to particular social groups (e.g., donating food to community fridges). Three independent judges (psychologists) rated each response on three dichotomous scales to establish (1) whether the participant's response concerns an actual behaviour; (2) whether it may occur more than once a month; and (3) whether it can be culturally universal. By doing so, we limited the list of items only to those that may be potentially exhibited frequently and those that could be understood in wider social groups. As a result, 104 behaviours were unanimously judged as fulfilling these criteria. The behaviours were reformulated so they could be used as items in a questionnaire.

Based on the results of the first study, we developed a 104-item questionnaire for measuring the frequency of behaviours associated with food wasting. Participants were asked to use a 7-point scale to assess how frequently they behaved in a given way. The authors distributed the questionnaire through a snowball sampling method by posting a link to the study on their social media. After the completion, each participant was asked to post the link on their social media pages. We aimed to gather a sample suitable for conducting exploratory factor analysis (EFA) and confirmatory factor analysis (CFA). According to 
Goretzko and colleagues (2019), the lower bound of 300 cases for conducting EFA and 300 cases for conducting CFA could be sufficient.

The final sample consisted of 612 participants ( 444 women; 163 men; 5 people identified themselves as non-binary; age $M=28.1, S D=8.02$; one participant who declared to be 222 years old was excluded from the analyses). The study was conducted on September 2-25, 2019.

The sample was divided into halves to obtain two independent samples with similar characteristics. Firstly, the data were ordered by participants' gender and age. Secondly, participants with even case-numbers formed Sample $1(n=306)$, and participants with odd case-numbers formed Sample 2 $(n=306)$. Both samples were identical in the distribution of gender and near-identical concerning mean age.

We conducted EFA on the first half of the sample with the principal axis factoring and Promax rotation (according to recommendations by Goretzko and colleagues; 2019). The factors retention was decided according to multiple criteria (parallel analysis, scree test, the variance accounted for each factor, and theoretical criteria). After establishing the items that reflect the factor structure best, we measured the internal consistency of each factor with Cronbach alpha.

In the second half of the sample, we conducted a CFA with maximum likelihood estimation. We used multiple cut-off criteria (CFI, RMSEA, SRMR, expected parameter change and modification index).

All the analyses were performed using the Jamovi software (version 1.6.9; The jamovi project, 2020). The methods, analyses, and hypotheses for this study were pre-registered (hidden for blind review - file attached to the submission) and the data are available online (hidden for blind review - file attached to the submission). 


\subsection{Results}

\subsubsection{Exploratory Factor Analysis}

The correlation matrix of 104 items was suitable for factor analysis (KMO = .86; Kaiser \& Rice, 1974). The scree test analysis suggested that there are five factors, therefore, we conducted our analyses for five fixed factors. Finally, we extracted four items per factor that best fitted the theoretical structure.

We conducted reliability analyses to test the internal consistency. The five factors included items that were describing (1) behaviours of discarding an edible food that has become unpalatable $(\alpha=.77)$; behaviours of buying food according to one's needs $(\alpha=.82)$; behaviours of planning one's meals and groceries $(\alpha=.79)$; behaviours associated with sharing the excess food with other people $(\alpha=.84)$; behaviours associated with feeding the excess food to animals $(\alpha=.94)$.

\subsubsection{Confirmatory Factor Analysis}

The path diagram for confirmatory factor analysis is presented in Figure 1. All indicators showed a good model fit: $\chi^{2}(160)=279, p<.001 ; \mathrm{CFI}=0.95 ; \mathrm{RMSEA}=0.05 ;$ SRMR $=0.06$ (Brown, 2015; Hu \& Bentler, 1999). The modification indices suggested modifications to our model, but we found no sound theoretical justification for doing so. The questionnaire is presented in the Supplement. 
Figure 1

Path diagram for the confirmatory factor analysis with standardized estimates for five categories of behaviours causing and preventing food waste

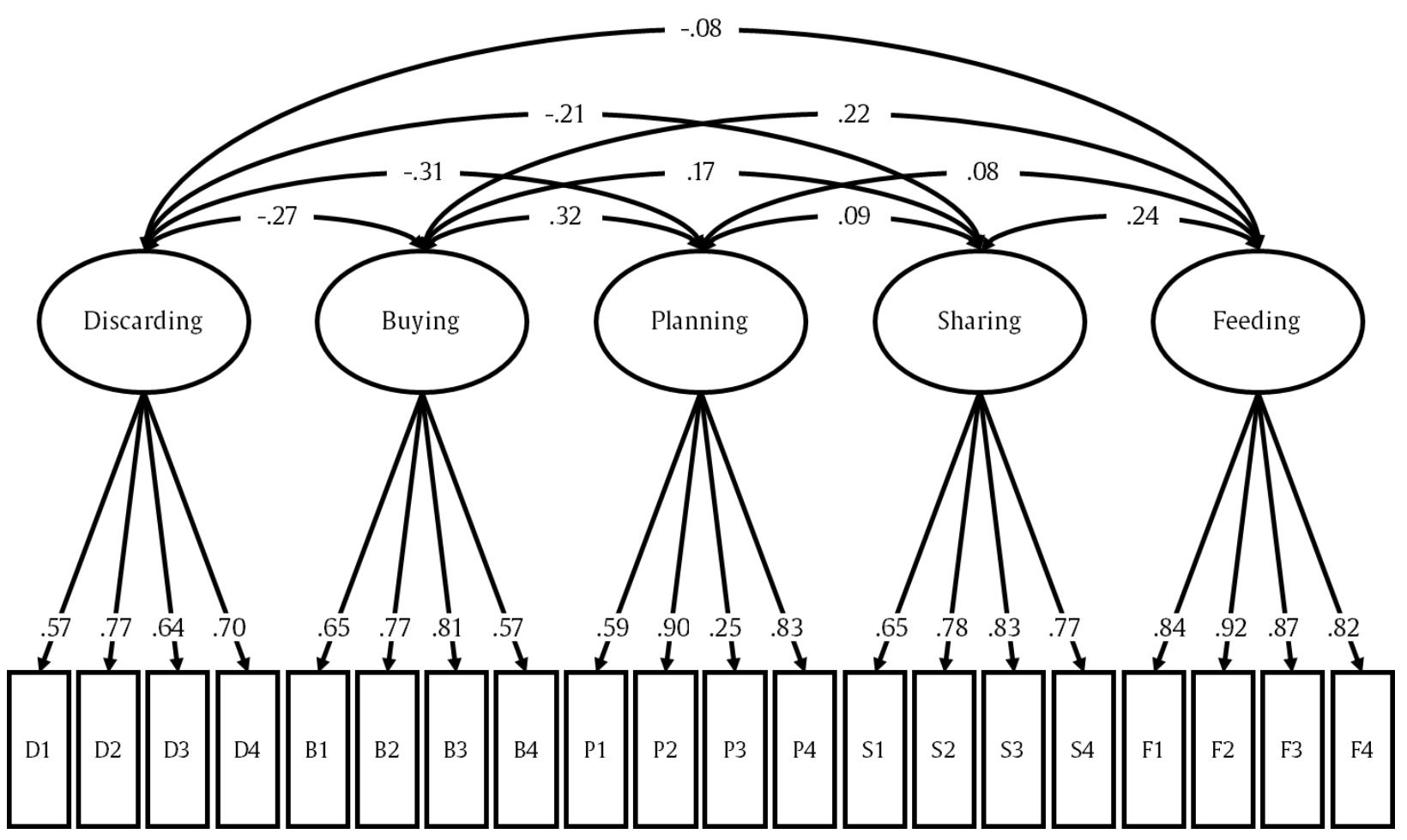

Note. Factor variances $=1$

\subsection{Summary}

We found that behaviours associated with food wasting could were linked to five distinctive factors: (1) discarding food because of its' unpalatability; (2) preventing food waste through buying only the necessities; (3) preventing food waste through planning meals and groceries; (4) preventing food waste through sharing food with others; and (5) preventing food waste through feeding animals. These categories are associated with our hypothesis based on the categories described in the Food Recovery Hierarchy (FRH) (Environmental Protection Agency, 2015). The first category in the FRH describes methods of source reduction -in other words, methods for managing the surplus of food. Two of the factors we found directly related to this category: buying and planning. Other categories described by FRH are 
feeding hungry people and feeding animals. The results of our study also reflected these two categorieswe found factors associated with food sharing and feeding animals. However, the list of our factors differed from FRH in two ways. First, we did not find a factor describing composting of foods. This behaviour was mentioned by the participants in the first part of the study (see Supplementary Materials), however, it did not emerge as a factor in the herein analyses. Second, we found a factor that is not associated with FRH: wasting food due to its' unpalatability. This is the only factor that emerged from the list of behaviours associated with discarding edible foods, whereas buying, planning, food sharing, and animals feeding emerged from the list of behaviours that prevent food from spoilage.

\section{Study 2}

In the second study, we aimed to verify whether the frequency of behaviours assessed through the FWBQ corresponds to the amount of wasted food. To date, studies demonstrated that self-descriptive questionnaires fail to reliably assess the actual amount of wasted food (van Herpen, et al., 2019). Although the FWBQ is not intended to make precise assessments of the amount of wasted food, we wanted to verify whether it can draw any relations between particular factors of food wasting behaviours and the amount of food waste.

We hypothesized that people who declared to display behaviours associated with food wastage, as measured through the FWBQ, will also declare higher amounts of discarded food products: people who scored higher on (1) food unpalatability, and those who scored lower on (2) buying, (3) planning, (4) sharing, (5) feeding, waste the larger amount of food products. We limited the list of food products to three categories that are associated with the highest negative environmental impact when wasted: meat, dairy, and bakery (Schmidt \& Matthies, 2018). The whole supply chain of these products (e.g., production, transportation and storage) contributes the greatest amount of greenhouse gases, and therefore leaves the greatest carbon footprint (Röös et al., 2014). Furthermore, meat, dairy and bakery are also the types of foods that are wasted the most frequently in Poland (Banki Żywności, 2020). 


\subsection{Methods}

The study was distributed in social media using the snowball sampling method, which gathered a sample of 683 people (531 women, 149 men, and 3 people who identified their gender as non-binary; age $M=30.6, S D=8.58)$. We initially planned to gather responses from 100 participants, to conduct a multiple linear regression to detect effect sizes of 0.20 with an alpha level of 0.05 and the power of 0.95 , but we non-intentionally overshoot this number.

To measure the frequency of food wasting behaviours, we used the FWBQ. To measure the amount of wasted food, we used a short questionnaire adapted from the study by Schmidt \& Matthies (2018). To facilitate the recollection of past-week memories of food wasting behaviours, each participant was asked to count how many times they threw away the edible foods (meat, dairy, bakery products, separately). After responding to this question, each participant was asked to estimate the amount of food wasted in three categories (measured in grams): meat, dairy, and bakery products with three examples accompanying each of the three questions, i.e., Try to estimate how many grams in SUM the meat weighed (e.g., sausage - about 85g, pork chop - about 130g, a slice of ham - about 15g).

First, we conducted a confirmatory factor analysis to see whether the structure of the questionnaire replicated. Then, we performed four ordinal logistic regressions with the amount of wasted food in each category as dependent variables. We decided to conduct non-parametrical tests as we found that measures of food wasted in grams were not distributed normally (skewness for meat $=12.2$; dairy $=$ 5.95; bakery products $=20.7$; a composite score $=14.6)$. We included the FWBQ factors scores, gender, age and being a vegan or vegetarian as predictors. To minimize the type I error, we used a Bonferroni correction- the alpha level below 0.013 was treated as significant. For exploratory purposes, we also looked at alpha levels of .05 , as these might suggest associations worth testing in future studies.

To conduct exploratory analyses, we asked whether a participant takes care of a pet, is vegan or vegetarian, is responsible for preparing meals in a household, is responsible for groceries, how many 
people live in a household, and we assessed peoples' body mass index. The exploratory analyses are presented in the Exploratory analyses section.

All the analyses were performed using the Jamovi software (version 1.6.9; The jamovi project, 2020). The methods, analyses and hypotheses for this study were pre-registered (hidden for blind review file attached to the submission).

\subsection{Results}

The confirmatory factor analysis supported the proposed structure of the questionnaire: $\chi^{2}(160)=$ $696.47, p<.001 ; \mathrm{CFI}=0.92 ; \mathrm{RMSEA}=0.07 ; \mathrm{SRMR}=0.05$. The complete results of the analyses are presented in Tables S2-S5 in the Supplementary Material. The models were statistically significant: the Meat model: $\mathrm{R}^{2}{ }_{\mathrm{MCF}}=0.05, p<.001$; the Dairy model: $\mathrm{R}^{2}{ }_{\mathrm{MCF}}=0.03, p<.001 ;$ the Bakery model: $\mathrm{R}^{2} \mathrm{McF}=0.03$, $p<.001 ;$ the Summed model: $\mathrm{R}^{2} \mathrm{McF}=0.03, p<.001$.

We found that people who more frequently discarded food due to its' unpalatability wasted more meat $(O R=1.09, p<.001)$, more dairy $(O R=1.08, p<.001)$, more bakery $(O R=1.12, p<.001)$ and more food in general $(O R=1.13, p<.001)$. People who less frequently bought food according to their needs (over shopped more) wasted more meat $(O R=0.93, p=.002)$ and more food in general $(O R=0.95, p=$ $.001)$. People who less frequently shared their food, wasted more dairy $(O R=0.96, p=.013)$.

\subsection{Study Summary}

The results suggested that the Food Wasting Behaviour Questionnaire might be suitable for tracking the actual amount of wasted food. The analyses also highlighted that different categories of behaviours contribute to various types of waste. We found that people who more frequently wasted food because of its unpalatability wasted more food, and this pattern was observed in all food categories. We also found that people who over shopped more wasted more meat and food in general, and those who shared less frequently wasted more dairy.

Our findings confirm that to assess the amount of wasted food through a questionnaire, it is necessary to acknowledge different types of food wasting behaviours. Furthermore, specific kinds of food 
wasting behaviours might lead to the waste of specific food products. The study suggests that the most apparent relationship between behaviours and the amount of wasted food occurs in the case of wasting motivated through foods unpalatability. This, in turn, suggests a promising entry point for designing interventions to limit consumer food wasting behaviour-for example, through designing methods of keeping food products more appetising for longer (Schmidt \& Matthies, 2018).

\section{Study 3}

In Study 3, we aimed at verifying whether the COVID-19 pandemic influenced people's behaviours associated with food wasting behaviours. The study sample was composed of the people who took part in Study 1 and declared the willingness to participate in future studies. The study was conducted on March 25-30, 2020, soon after World Health Organization declared the COVID-19 outbreak a pandemic (March 11), and the Polish government introduced the state of the epidemic in the country (March 20). We aimed to verify whether the state of the COVID-19 pandemic influenced the behaviours associated with food wasting and food waste prevention. The pandemic disturbed the global food system (Laborde et al., 2020, p. 019). It has also influenced the day-to-day household food practices through increasing food insecurity (Devereux et al., 2020), which resulted in panic buying of food products (Eder et al., 2020; Hobbs, 2020).

Based on the literature on food insecurity and hunger (Al-Shawaf, 2016; Nettle, 2017; Nettle et al., 2017, 2019), we hypothesized that individual food insecurity would change the behaviours associated with food wasting and preventing behaviour during the pandemic. Specifically, compared to the time before the pandemic, we expected people to (1) less frequently discard unpalatable foods, because in the time of food insecurity food might be perceived as less available, therefore more valuable; (2) less frequently buy according to their needs, because in the time of food insecurity, people might want to hoard food; (3) less frequently plan their meals, as food insecurity may increase anxiety, which interferes with planning; (4) less frequently share food and less frequently feed animals, because in the time of food insecurity people, 
might want to assure their food availability. We controlled for individual food insecurity, as we hypothesized its' moderating effect.

\subsection{Methods}

We have sent invitation e-mails to the participants that declared their willingness to participate in the second part of the study. Additionally, we sent three follow-up messages to people who did not respond to the invitation e-mail. Out of 518 participants that took part in Study 1 and agreed to receive an invitation for a second study, we gathered the responses of 262 of them (199 women, 63 men; age $M=$ 28.6 $S D=7.56)$. This sample is smaller than the pre-registered plans $(n=327)$, and, therefore, the study was able to achieve a power of 0.85 for small effect sizes $(d=0.21$; the smallest significant effect in our study) in matched pair t-tests with an alpha level of 0.01 (Faul et al., 2009). Given that the within-subject study could be conducted only among the people who participated in Study 1, we could not increase the size of the sample by recruiting new participants.

We used the FWBQ for assessing the frequency of food wasting behaviours. For measuring food insecurity, we used the Adult Food Insecurity scale (AFI; Nettle et al., 2019). AFI is a 20-item scale that assesses the level of current food insecurity-the higher the score, the higher the probability that the individual is experiencing food insecurity.

We conducted a set of one-sided paired samples t-tests to verify whether the frequency of behaviours associated with food wasting changed during the pandemic. In the second step, we conducted correlational analyses to verify whether Adult Food Insecurity predicts any of the behaviours associated with wasting food during the pandemic. Finally, we conducted repeated-measures ANCOVA with AFI as a covariate to verify whether food insecurity is associated with the shift in the frequency of food wasting behaviours. We used a p-value of 0.005 to correct for multiple comparisons.

All the analyses were performed using the Jamovi software (version 1.6.9; The jamovi project, 2020). The methods, analyses, and hypotheses for this study were pre-registered (hidden for blind review - file attached to the submission). 


\subsection{Results}

Descriptive statistics and test statistics are presented in Table 2. The scores with the effect sizes are presented in Figure 2.

The mean score for planning meals during the pandemic was higher than the score before the pandemic. Therefore, we found no support for our hypothesis of a decrease in meal planning behaviours during the pandemic. A two-sided paired t-test suggests that the relationship is significant, although in the opposite direction.

\section{Table 2}

Descriptive statistics and test statistics for comparisons of the frequency of behaviours associated with food wasting before and during the pandemic.

\begin{tabular}{lccccc}
\hline & $\begin{array}{c}\text { Before } \\
\text { pandemic }\end{array}$ & $\begin{array}{c}\text { During } \\
\text { pandemic }\end{array}$ & & & \\
\cline { 2 - 4 } Categories of behaviours & $M(S D)$ & $M(S D)$ & $t$ & $<.001$ \\
\hline Discarding unpalatable foods & $11.13(4.83)$ & $10.11(4.75)$ & 3.71 & 3.33 & $<.001$ \\
Buying as needed & $18.62(4.82)$ & $17.47(5.16)$ & -001 \\
Planning meals & $20.99(5.01)$ & $23.06(4.09)$ & -7.48 & .065 \\
Sharing food & $11.35(6.13)$ & $10.79(6.23)$ & 1.52 & .018 \\
Feeding animals & $10.45(7.30)$ & $9.68(7.27)$ & 2.11 & \\
\hline
\end{tabular}

Note. To correct for multiple comparisons, we used a p-value of .01. The $p$-value for the differences in planning behaviours is given for a two-sided t-test as our initial hypothesis was not confirmed. 
Figure $2<$ no colour in print $>$

Box plots with medians (line), means (x), and distribution ranges for five categories of behaviours causing and preventing food waste: discarding unpalatable foods (Discarding), buying as needed (Buying), planning meals (Planning), sharing food (Sharing), and feeding animals (Feeding). For each behaviour the first box plot for behaviours preceding the pandemics and the second for behaviours during the pandemics

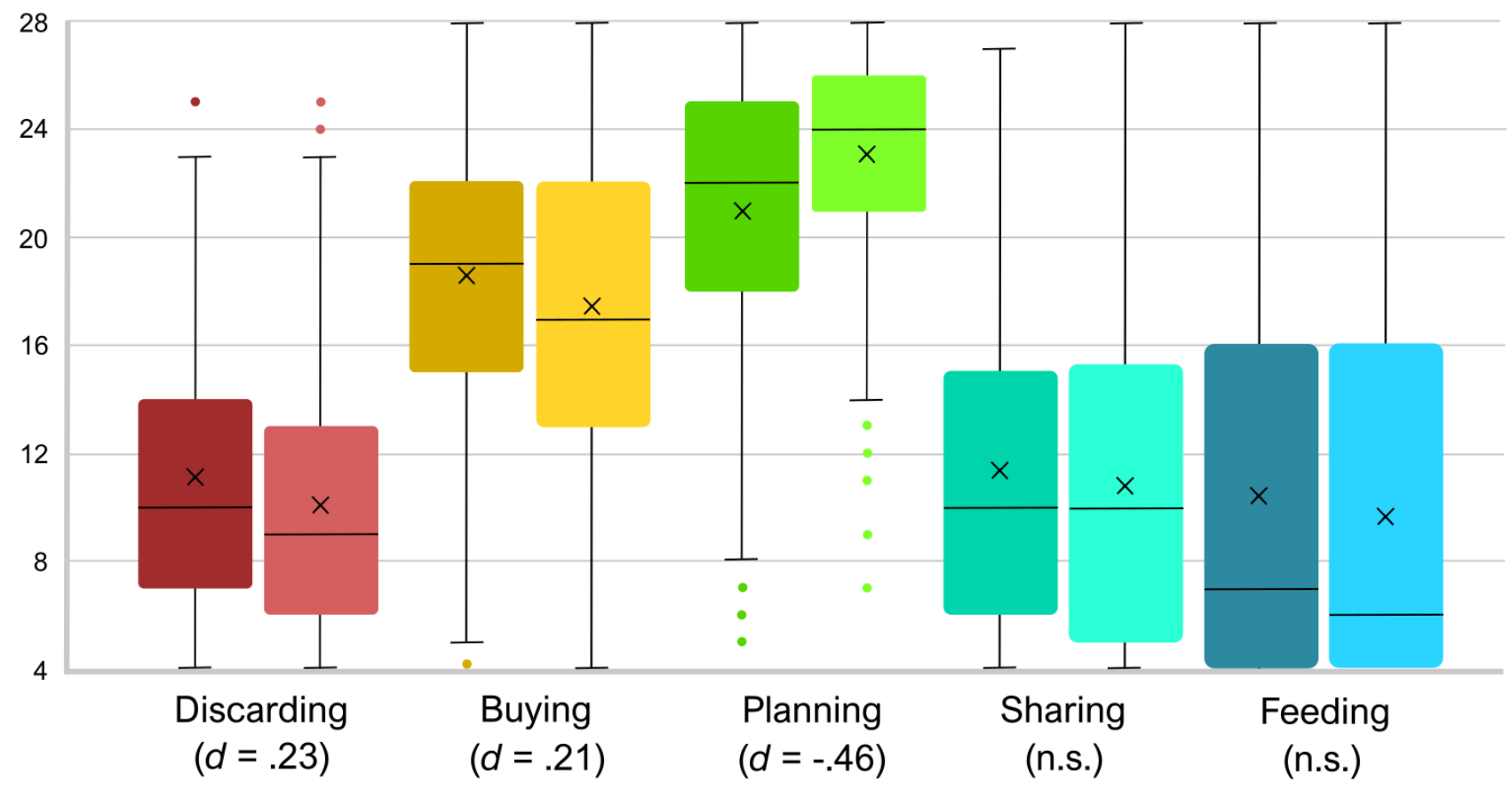

Note. The lowest number a person can score on the FWBQ is 4 . Therefore, the bottom of the chart starts with this number.

The Adult Food Insecurity scale was reliable $(\alpha=.76)$. We found no significant relationship between AFI scores and the scores of different categories of food wasting behaviours except for a negative relationship with planning meals $(r=-.16 ; p=.012)$.

To further our understanding of the relationship between AFI and planning behaviour, we decided to exploratively test whether AFI is linked to the planning behaviour before the pandemic (as measured in Study 1). We found a correlation in the same direction and of similar effect size as the correlation between 
AFI and planning behaviour during the pandemic $(r=-.15 ; p=.019)$. We considered this correlation as reliable and tested whether the AFI score interacts with the effect of the pandemic on the shift in meal planning behaviour. Yet, there was no significant interaction effect between AFI and the change in the frequency of planning meals $(F(1,260)=.11 ; p=.74)$.

\subsection{Summary}

We found that during the pandemic, people shifted their behaviours concerning food wasting. They were less frequently discarding unpalatable foods and more frequently overbuying food products. Contrary to our hypothesis, people were more frequently planning their meals and groceries. There were no differences in behaviours associated with sharing food and feeding it to animals before and during the pandemic. Additionally, we found that people who experienced greater food insecurity were planning their meals less frequently.

The results of Study 3 demonstrate that the FWBQ is suitable for tracking the patterns of food wasting behaviour that are caused by situational changes and individual living conditions. The situational change was determined by the COVID-19 pandemic. Our results suggest that people minimized some of their food wasting behaviours. We believe that the change was associated with lockdown-type measures introduced to restrict the virus transmission. People who spent more time in their households had fewer opportunities to buy foods, so they bought the food items in bulk. They also were not able to use the foodservice, so they had to plan and prepare their meals more frequently. This could result in more opportunities to use less palatable foods in cooking, so it limited the amount of discarded food.

Individual life condition, food insecurity, predicted the behaviours associated with meal planning. People who experienced a greater level of food insecurity were less likely to plan their meals. It could be that people who have harder access to foods do not have so many opportunities to plan their meals, because they are more frequently using what is available at present, without considering the future. 


\section{Exploratory Analyses}

In the process of conducting four previous studies, we have gathered additional data to explore whether the FWBQ might provide any additional insights. We did not pre-register the analyses listed below. We assembled the databases from Study $1 \mathrm{~b}$ and Study 2 (Study 3 was conducted on the same participants as Study 1b, therefore we did not include this database), in which we collected data on participants' gender and age ( $N=1287$; 975 women, 312 men, 4 people self-identified as non-binary; mean age $=29.4, S D=8.41)$. In Study 2, we also asked whether a participant takes care of a pet, is vegan or vegetarian, is responsible for preparing meals in a household, is responsible for groceries, and how many people live in a household, and we assessed peoples' body mass index.

\subsection{Analyses}

We conducted a set of multiple regression analyses to test whether (1) gender, (2) age, (3) taking care of a pet, (4) being vegetarian or vegan, (5) being responsible for cooking in a household, (6) being a person responsible for groceries in a household, (7) number of people living in a household, and (8) BMI predicted the frequency of behaviours in each factor of the FWBQ. As these were the exploratory analyses, we decided to set the alpha level to .05 to observe as many potential associations as possible between the FWBQ and explored variables. We also looked at the Variance Inflation Factor to control for multicollinearity.

\subsection{Results}

The results of multiple linear regression models are presented in Supplement, in Table S6.

\subsection{Summary of the explorative analyses}

The exploratory analyses suggested that each category of food wasting behaviours, as measured with the FWBQ, is associated with various demographic factors. Results revealed that food wasting behaviours could be partially associated with gender, age, taking care of a pet, being vegetarian or vegan, being the main cook in a household, number of people living in a household, and BMI. 
- $\quad$ Older participants less frequently discarded food due to its' unpalatability, less frequently shared food surplus with other people, and less frequently fed animals with leftovers.

- Women, compared to men, more frequently planned meals and groceries, more frequently shared food with others.

- $\quad$ People who took care of a pet, compared to those who did not, more frequently fed animals with food leftovers.

- Vegetarians and vegans, compared to people who did not indicate they are vegetarians or vegans, less frequently discarded food due to its' unpalatability, more frequently bought food according to their needs, and less frequently fed animals with leftovers.

- $\quad$ People who identified themselves as the main cooks in their households more frequently planned meals and groceries.

- $\quad$ People who lived in larger households more frequently shared food leftover with animals.

- $\quad$ People with a greater body mass index less frequently planned their meals and groceries.

\section{Discussion}

This paper describes three studies that established a novel method for preliminary measurement of consumer food wasting behaviours - Food Wasting Behaviours Questionnaire (FWBQ). In Study 1, we developed a five-factor questionnaire that included the behaviours associated with discarding food and behaviours that prevent food from being wasted. In Study 2, we demonstrated how these categories of food wasting behaviours are associated with wasting meat, dairy, and bakery products. In study 3 , through observing the behaviour shift during the COVID-19 lockdown, we demonstrated that the FWBQ allows for monitoring changes in food wasting behaviours and that it allows for associating individual characteristics, like the level of individual food insecurity, with food wasting behaviours. After testing the pre-registered hypotheses, we conducted exploratory analyses to verify whether the FWBQ factors might be predicted by various demographic variables. 
The results of the studies suggest that a very wide list of food wasting behaviours and those that prevent food from being wasted could be narrowed down to five factors. The first one is the only one associated with direct food wasting: discarding food due to its unpalatability. The other four factors include behaviours that prevent food from being wasted: buying food according to one's needs, planning meals and groceries, sharing the surplus of food with others, and feeding animals. These categories of behaviours were previously studied separately through various methods. The FWBQ allows for studying them all at once and makes observing the relationship between these behaviours possible. Furthermore, the fact that these behaviours are clustered into factors means that they might operate independently and through different psychological and situational mechanisms.

(1) Discarding food due to its' unpalatability-this factor describes a group of wasting behaviours motivated through the quality of food. People who score high on this factor more frequently discard food because it appears to them as unappetizing. This factor might be based on the affective reaction of disgust, as spoiling foods is an elicitor of this reaction (Hartmann \& Siegrist, 2018) - previous research has shown that people who are more disgust-sensitive tend to waste more food (Egolf et al., 2018). In our exploratory analyses, we found that older people scored higher on this factor - it is consistent with previous research that suggests older people are less sensitive to cues of disgust (Curtis \& de Barra, 2018). Furthermore, we found vegetarians and vegans to less frequently discard food due to its' unpalatability. This could be a result of the fact that these types of diets do not include the most spoilage-vulnerable products, like meat (Dave \& Ghaly, 2011). It could also be a result of greater environmental awareness: people who reduce their meat intake are often motivated by pro-environmental reasons and these underlie reduction in food-wasting as well (Kim et al., 2020).

(2) Buying food -this factor consists of behaviours associated with buying according to ones' need and avoiding over shopping. Previous research documented that people who over shop waste more food and addressing this behaviour might be a promising method for reducing food waste (Canali et al., 2017). Furthermore, over shopping could be driven by psychological mechanisms, like a good provider 
identity (Visschers, et al., 2016). People who identify as good providers need to have plenty of food on hand to ensure they could feed their loved ones and manifest their hospitality. At the same time, it increases the probability of wastage, as perishable foods might never be used to serve their social function (Schanes et al., 2018). In the exploratory analyses, we found that vegetarians and vegans more frequently bought their food according to their needs and over shopped less. It could be that the environmental awareness of vegetarians and vegans reframes their understanding of being a good provider - they might see their diets as a way of benefitting something beyond themselves and their immediate social group, like the animals and the environment (Rosenfeld, 2020).

(3) Planning meals - this factor underlies the behaviours associated with planning meals and planning grocery shopping. The planning routines regarding these two domains might contribute to consumer food waste the most (Romani et al., 2018). Unlike other factors, planning behaviour requires the most intentional and deliberate actions to be undertaken before the food acquisition and consumption, like mastering cooking methods and controlling food purchases with a shopping list (Stancu et al., 2016). The exploratory analyses showed that women are planning more frequently. At the same time, people who are the main cooks in their households also plan more frequently. This finding suggests that food wasting behaviours could be associated with gender in some other way than through traditionally determined sexual division of responsibilities around food preparation (Jungowska et al., 2021). Koivupuro and colleagues (2012) speculated that gender differences in food wasting behaviours might be a result of peoples' switch to healthier lifestyles and women's intention to buy fresh and healthy foods for the family. The link between a healthy lifestyle and wasting behaviour was also highlighted with our finding that those with lower BMI planned their meals and groceries more often - that could be explained by the fact that people who stick to a dieting regime more frequently plan their energy and nutrient intake.

(4) Sharing food with others - this factor is rarely described as a potential method to minimise food waste, although it has been acknowledged that people who want to minimize food wasting engage in food sharing (Schanes \& Stagl, 2019). It has been hypothesized that food sharing cultural norms might 
serve as a strategy to avoid food wasting in small-scale societies (Misiak et al., 2019) and that there might be a specific psychological tendency that favours sharing food over sharing other objects (Sorokowska et al., 2021). Yet, people living in industrialised western societies, in which the majority of studies on food waste is conducted, waste their food in households, where the visibility of this behaviour to other people is minimal (Quested et al., 2013). The exploratory analyses suggested that women and younger people tend to share the surplus of food more often - a finding that is also reflected in the demographic structure of people that engage in food sharing initiatives (Ganglbauer et al., 2014; Schanes \& Stagl, 2019).

(5) Feeding animals - this factor underlies the behaviours associated with using food leftovers to feed pets and other animals. These behaviours could be controversial, as feeding animals with human food could be perceived by consumers as a way to reduce food wastage, but on the other hand, it could contribute to animals' health problems (Dodd et al., 2020). In our exploratory analyses, we found that people who more frequently fed the leftovers to animals were taking care of a pet, were younger, lived in bigger households, and less frequently were vegetarian or vegan. We believe that the relationship with age and household size could be explained by the economic status: people who have a smaller budget for pet care (younger ones and those who have bigger families) may save money by substituting commercial pet food with leftovers. Less frequent animal feeding by vegetarians and vegans could be explained by their better nutritional knowledge and their awareness of potential hazards associated with feeding animals with human food.

Specific kinds of behaviours may contribute to specific food products being wasted. In our project, we looked at foods that were associated with the biggest environmental impact when wasted: meat, dairy, and bakery (Schmidt \& Matthies, 2018). We found that discarding food due to its' unpalatability was the best predictor of the amount of wasted meat, bakery and dairy. These are all products that quickly lose their sensory qualities. People who do not mind eating food products that lost their appeal might be less sensitive to the cues of spoilage. It could be that the change in food structure elicits a disgust response, therefore, disgust-sensitive people are more likely to discard it (Ammann et al., 2018). Also, 
FWBQ allowed indicating that people who more frequently bought food according to their needs (over shopped less frequently) wasted less meat. Meat is a food product with a short expiry date, and over shopping could lead to problems with managing the surplus of this perishable vulnerable food product. We have also found that people who more frequently share the surplus of food waste less dairy. It could be that a commercial package of dairy products (e.g., yoghurt, milk, cottage cheese) facilitates sharing. Meat and bakery are often sold with no airtight packaging - this allows consumers to buy the exact amount of meat and bakery they want, but it also excludes these products from further sharing as it raises concerns about the safety of consuming it. In sum, these findings provide directions for people who want to design interventions aimed at decreasing the wastage of food products with the most negative environmental impact (Schmidt \& Matthies, 2018). Our research suggests that focusing on minimizing food unpalatability, e.g., through improving the packaging methods or through educating people on food storing techniques, might be the most effective in minimizing household food wastage (Reynolds et al., 2019).

Food Wasting Behaviours Questionnaire demonstrated its' utility in predicting situational and individual factors underlying food wasting behaviours. The COVID-19 pandemic allowed us to observe how food wasting behaviours change during extreme disturbances in daily practices and routines. Our research design included measurements before and during the pandemic, which makes our study a natural experiment. We demonstrated that the situational changes associated with the COVID-19 pandemic decreased discarding food due to its' unpalatability, increased overbuying of foods, and contrary to our expectations, increased planning of meal consumption. We believe that the changes in food wasting behaviours were caused by the lockdown-type measures that were introduced to mitigate the transmission of the virus. First, the authorities discouraged people from leaving their homes. This resulted in so-called "hamster purchases" - people were overbuying to ensure their food safety (Eder et al., 2020). Because people limited the frequency of grocery shopping, they were less likely to get fresh food every day. Our research demonstrated both phenomena-people less frequently bought groceries according to 
their needs (they overshopped) and they less frequently discarded unpalatable foods (they decided to consume their foods, even when it was less appealing). However, we did not expect that people will plan their meals more frequently-we predicted that all the behaviours associated with planning will decrease, as the lockdown destabilized regular household routines. It could be that in the face of potential food shortages people are focusing on better food management. Although the results go against our hypothesis, the increase in planning during the pandemic was also observed in other studies (Jribi et al., 2020; Principato et al., 2020). In sum, the study on consumer food wasting behaviour during the pandemic with the use of the FWBQ demonstrates the shift in behaviours: people were more willing to consume unpalatable foods, more frequently planned their meals, but also overbought more food.

The FWBQ also allowed us to observe an individual factor that shapes consumer food wasting behaviours-food insecurity. We found that people who had more problems with access to food as well as those for whom more nutritious diets were out of reach, planned their meals less frequently than people with better access. Furthermore, the level of food insecurity measured during the pandemic also was related to lower scores on planning behaviours before the pandemic. It could mean that the pandemic did not influence this pattern, and food insecurity interfered with planning behaviours also before the pandemic. These findings are not surprising, as it is hard to plan one's meals if the access to food is limited or unpredictable. Previous studies already argued that food insecurity influences food wasting behaviour-however, the prediction was that higher levels of food insecurity decrease the levels of food waste (Misiak et al., 2018). As less frequent meal planning is associated with increased wastage, the results of our study seemingly contradict this prediction. Nevertheless, it is not necessarily the case: if people are not planning their meals because they do not have access to food, their lack of planning cannot contribute to food wastage. This nuances the argument that lack of planning causes food wastage (Stefan et al., 2013) -it does, but not if the lack of planning is a result of lack of food. 


\subsection{Limitations and future directions}

The Food Wasting Behaviours Questionnaire allows for measuring the frequency of five categories of behaviours associated with food wasting. However, it is important to stress that these five categories do not include all possible factors that contribute to food wastage. We aimed to develop a short questionnaire suitable for conducting preliminary research on food wasting in various types of populations, therefore, we included only the behaviours that could be easily comprehended by people of different demographic and cultural backgrounds. Future studies might demonstrate more populationspecific categories of food wasting behaviours. For example, people living in rural areas might limit their food wasting through composting. Composting was a kind of behaviour that was described by participants as the behaviour that limits the food wasting in the preliminary part of Study 1, however, the factor analysis excluded it as a potential factor. This does not mean that this category would not emerge if we conducted our study in a different population, where composting is more popular.

A similar logic applies not only to the number of possible categories of food wasting behaviours but also to the frequency of each behaviour in a given population. Our study suggests that wasting food due to its' unpalatability, food sharing, and feeding animals are much less frequent than behaviours associated with buying foods and planning. This pattern of results is likely specific to our sample. We hypothesize that the FWBQ would yield different results if the study was conducted in a different population. For example, if we were to use the FWBQ among the people whose culture stresses the importance of food sharing, we might expect the scores on the food sharing category to be much higher. Similarly, if we conducted a study in a population with limited access to electricity, we might expect people to overbuy less, as it would be harder to store the food surplus.

We want to stress that the questionnaire is not suitable to replace the methods which measure the total amount of wasted food. We never aimed to do so. The FWBQ should be used as a preliminary method for assessing food wastage: it is suitable for verifying the hypotheses on the causes of food 
wasting behaviours, it also allows for monitoring the change in peoples' practices and routines, but it does not allow to evaluate the total amount of consumer food waste.

We believe that using the FWBQ in future studies could extend our understanding of consumer food wasting behaviours in two main ways. First, it has been constructed with the premise to allow for using it in various populations. The field of food wasting research has been dominated by studies that are conducted on western industrialized populations. However, the problem of food wasting concerns people all over the world. The FWBQ was designed to be comprehensible by people of various cultural, religious, and demographic backgrounds-because of that it might be suitable for conducting cross-populational comparisons. This potential advantage of the questionnaire should be tested in future studies. The second strength of the FWBQ lies in its' potential for using it in systematic quantitative reviews, like metaanalyses. To date, researchers published several large reviews on consumer food wasting behaviours (e.g., Principato, 2018; Schanes et al., 2018), but the diverse methods used in the field are not suitable for conducting meta-analyses.

\subsection{Conclusion}

Overall, our multi-study project introduces the Food Wasting Behaviours Questionnaire-a new method for preliminary research on consumer food wasting behaviours. It highlights the five categories of food wasting behaviours that are associated with food wasting: (1) discarding unpalatable foods, (2) overbuying foods, (3) planning meals and groceries, (4) sharing foods with others, and (5) feeding animals. We demonstrated the utility of the FWBQ in assessing the behaviours in different situational contexts (the pandemic lockdown) and as a result of individual characteristics (food insecurity). We also pointed to different categories of food waste that could be predicted only through acknowledging categories of food wasting behaviours. We believe that this approach would yield novel findings that could be systematically analysed to tackle the problem of food waste successfully. 


\section{References}

Al-Shawaf, L. (2016). The evolutionary psychology of hunger. Appetite, 105, 591-595. https://doi.org/10.1016/j.appet.2016.06.021

Banki Żywności. (2020). Nie marnuj jedzenia 2020. Raport Federacji Polskich Banków Żywności.

Boulet, M., Hoek, A. C., \& Raven, R. (2020). Towards a multi-level framework of household food waste and consumer behaviour: Untangling spaghetti soup. Appetite, 104856.

Bradbury, M., Peterson, M. N., \& Liu, J. (2014). Long-term dynamics of household size and their environmental implications. Population and Environment, 36(1), 73-84. https://doi.org/10.1007/s11111-014-0203-6

Brown, T. A. (2015). Confirmatory factor analysis for applied research. Guilford publications.

Canali, M., Amani, P., Aramyan, L., Gheoldus, M., Moates, G., Östergren, K., Silvennoinen, K., Waldron, K., \& Vittuari, M. (2017). Food waste drivers in Europe, from identification to possible interventions. Sustainability, 9(1), 37.

Chapagain, A. K., \& James, K. (2013). Accounting for the Impact of Food Waste on Water Resources and Climate Change. In M. R. Kosseva \& C. Webb (Eds.), Food Industry Wastes (pp. 217-236). Academic Press. https://doi.org/10.1016/B978-0-12-391921-2.00012-3

Curtis, V., \& de Barra, M. (2018). The structure and function of pathogen disgust. Philosophical Transactions of the Royal Society B: Biological Sciences, 373(1751), 20170208.

Dave, D., \& Ghaly, A. E. (2011). Meat Spoilage Mechanisms and Preservation Techniques: A Critical Review. American Journal of Agricultural and Biological Science. https://agris.Food and Agriculture Organization.org/agris-search/search.do?recordID=DJ2012079653

Devereux, S., Béné, C., \& Hoddinott, J. (2020). Conceptualising COVID-19's impacts on household food security. Food Security, 12(4), 769-772. https://doi.org/10.1007/s12571-020-01085-0 
Dodd, S., Cave, N., Abood, S., Shoveller, A.-K., Adolphe, J., \& Verbrugghe, A. (2020). An observational study of pet feeding practices and how these have changed between 2008 and 2018. Veterinary Record, 186(19), 643-643.

Eder, S. J., Stefańczyk, M., Pieniak, M., Molina, J. M., Binter, J., Pešout, O., Smela, P., Scharnowski, F., \& Steyrl, D. (2020). Food insecurity, hoarding behavior, and environmental harshness do not predict weight changes during the COVID-19 pandemic.

Egolf, A., Siegrist, M., \& Hartmann, C. (2018). How people's food disgust sensitivity shapes their eating and food behaviour. Appetite, 127, 28-36. https://doi.org/10.1016/j.appet.2018.04.014

Environmental Protection Agency. (2015). Food Recovery Hierarchy [Overviews and Factsheets]. https://www.epa.gov/sustainable-management-food/food-recovery-hierarchy

European Commission. (2021). EU Platform on Food Losses and Food Waste. Food Safety - European Commission. https://ec.europa.eu/food/safety/food_waste/eu_actions/eu-platform_en

Food and Agriculture Organization. (2019). The State of Food and Agriculture in the World. Moving forward on food loss and waste reduction. http://www. Food and Agriculture Organization.org/state-of-food-agriculture/en/

Faul, F., Erdfelder, E., Buchner, A., \& Lang, A.-G. (2009). Statistical power analyses using G*Power 3.1: Tests for correlation and regression analyses. Behavior Research Methods, 41(4), 1149-1160. https://doi.org/10.3758/BRM.41.4.1149

Ganglbauer, E., Fitzpatrick, G., Subasi, Ö., \& Güldenpfennig, F. (2014). Think globally, act locally: A case study of a free food sharing community and social networking. Proceedings of the 17th ACM Conference on Computer Supported Cooperative Work \& Social Computing, 911-921.

Goretzko, D., Pham, T. T. H., \& Bühner, M. (2019). Exploratory factor analysis: Current use, methodological developments and recommendations for good practice. Current Psychology, 1-12.

Hartmann, C., \& Siegrist, M. (2018). Development and validation of the Food Disgust Scale. Food Quality and Preference, 63, 38-50. https://doi.org/10.1016/j.foodqual.2017.07.013 
Hebrok, M., \& Boks, C. (2017). Household food waste: Drivers and potential intervention points for design - An extensive review. Journal of Cleaner Production, 151, 380-392. https://doi.org/10.1016/j.jclepro.2017.03.069

Hobbs, J. E. (2020). Food supply chains during the COVID-19 pandemic. Canadian Journal of Agricultural Economics/Revue Canadienne d'agroeconomie, 68(2), 171-176. https://doi.org/10.1111/cjag.12237

Houghton, R. A. (2012). Carbon emissions and the drivers of deforestation and forest degradation in the tropics. Current Opinion in Environmental Sustainability, 4(6), 597-603. https://doi.org/10.1016/j.cosust.2012.06.006

Hu, L., \& Bentler, P. M. (1999). Cutoff criteria for fit indexes in covariance structure analysis: Conventional criteria versus new alternatives. Structural Equation Modeling: A Multidisciplinary Journal, 6(1), $1-55$.

Intergovernmental Panel on Climate Change. (2018). Mitigation pathways compatible with $1.5^{\circ} \mathrm{C}$ in the context of sustainable development. In Global Warming of $1.5^{\circ} \mathrm{C}$ an Intergovernmental Panel on Climate Change special report on the impacts of global warming of $1.5^{\circ} \mathrm{C}$ above pre-industrial levels and related global greenhouse gas emission pathways, in the context of strengthening the global response to the threat of climate change. Intergovernmental Panel on Climate Change. https://www.Intergovernmental Panel on Climate Change.ch/report/sr15/ Jörissen, J., Priefer, C., \& Bräutigam, K.-R. (2015). Food waste generation at household level: Results of a survey among employees of two European research centers in Italy and Germany. Sustainability, 7(3), 2695-2715.

Jribi, S., Ben Ismail, H., Doggui, D., \& Debbabi, H. (2020). COVID-19 virus outbreak lockdown: What impacts on household food wastage? Environment, Development and Sustainability, 22(5), 3939-3955. https://doi.org/10.1007/s10668-020-00740-y 
Jungowska, J., Kulczyński, B., Sidor, A., \& Gramza-Michałowska, A. (2021). Assessment of Factors Affecting the Amount of Food Waste in Households Run by Polish Women Aware of Well-Being. Sustainability, 13(2), 976.

Kaiser, H. F., \& Rice, J. (1974). Little jiffy, mark IV. Educational and Psychological Measurement, 34(1), 111117.

Kim, M. J., Hall, C. M., \& Kim, D.-K. (2020). Predicting environmentally friendly eating out behavior by value-attitude-behavior theory: Does being vegetarian reduce food waste? Journal of Sustainable Tourism, 28(6), 797-815.

Koivupuro, H.-K., Hartikainen, H., Silvennoinen, K., Katajajuuri, J.-M., Heikintalo, N., Reinikainen, A., \& Jalkanen, L. (2012). Influence of socio-demographical, behavioural and attitudinal factors on the amount of avoidable food waste generated in Finnish households. International Journal of Consumer Studies, 36(2), 183-191. https://doi.org/10.1111/j.1470-6431.2011.01080.x

Laborde, D., Martin, W., Swinnen, J., \& Vos, R. (2020). COVID-19 risks to global food security. Science, 369(6503), 500-502. https://doi.org/10.1126/science.abc4765

Melikoglu, M., Lin, C. S. K., \& Webb, C. (2013). Analysing global food waste problem: Pinpointing the facts and estimating the energy content. Central European Journal of Engineering, 3(2), 157-164. https://doi.org/10.2478/s13531-012-0058-5

Misiak, M., Butovskaya, M., \& Sorokowski, P. (2018). Ecology shapes moral judgments towards foodwasting behavior: Evidence from the Yali of West Papua, the Ngorongoro Maasai, and Poles. Appetite, 125, 124-130. https://doi.org/10.1016/j.appet.2017.12.031

Misiak, M., Kruger, D., Kruger, J. S., \& Sorokowski, P. (2020). Moral judgments of food wasting predict food wasting behavior. British Food Journal, ahead-of-print(ahead-of-print). https://doi.org/10.1108/BFJ-07-2019-0576 
Misiak, M., Sorokowski, P., \& Karwowski, M. (2019). Does the "incentive hope" hypothesis explain foodwasting behavior among humans? Yes and no. Behavioral and Brain Sciences, 42. https://doi.org/10.1017/S0140525X18001942

Nettle, D. (2017). Does Hunger Contribute to Socioeconomic Gradients in Behavior? Frontiers in Psychology, 8. https://doi.org/10.3389/fpsyg.2017.00358

Nettle, D., Andrews, C., \& Bateson, M. (2017, ed). Food insecurity as a driver of obesity in humans: The insurance hypothesis. Behavioral and Brain Sciences; Cambridge University Press. https://doi.org/10.1017/S0140525X16000947

Nettle, D., Joly, M., Broadbent, E., Smith, C., Tittle, E., \& Bateson, M. (2019). Opportunistic food consumption in relation to childhood and adult food insecurity: An exploratory correlational study. Appetite, 132, 222-229. https://doi.org/10.1016/j.appet.2018.07.018

Nicholes, M. J., Quested, T. E., Reynolds, C., Gillick, S., \& Parry, A. D. (2019). Surely you don't eat parsnip skins? Categorising the edibility of food waste. Resources, Conservation and Recycling, 147, 179188. https://doi.org/10.1016/j.resconrec.2019.03.004

Papargyropoulou, E., Lozano, R., Steinberger, J. K., Wright, N., \& Ujang, Z. B. (2014). The food waste hierarchy as a framework for the management of food surplus and food waste. Journal of Cleaner Production, 76(10.1016/j.jclepro.2014.04.020), 106-115.

Parfitt, J., Barthel, M., \& Macnaughton, S. (2010). Food waste within food supply chains: Quantification and potential for change to 2050. Philosophical Transactions of the Royal Society B: Biological Sciences, 365(1554), 3065-3081. https://doi.org/10.1098/rstb.2010.0126

Porpino, G. (2016). Household Food Waste Behavior: Avenues for Future Research. Journal of the Association for Consumer Research, 1(1), 41-51. https://doi.org/10.1086/684528

Principato, L. (2018). Food Waste at Consumer Level: A Comprehensive Literature Review. Springer. 
Principato, L., Secondi, L., Cicatiello, C., \& Mattia, G. (2020). Caring more about food: The unexpected positive effect of the Covid-19 lockdown on household food management and waste. SocioEconomic Planning Sciences, 100953. https://doi.org/10.1016/j.seps.2020.100953

Quested, T. E., Marsh, E., Stunell, D., \& Parry, A. D. (2013). Spaghetti soup: The complex world of food waste behaviours. Resources, Conservation and Recycling, 79, 43-51. https://doi.org/10.1016/j.resconrec.2013.04.011

Romani, S., Grappi, S., Bagozzi, R. P., \& Barone, A. M. (2018). Domestic food practices: A study of food management behaviors and the role of food preparation planning in reducing waste. Appetite, 121, 215-227. https://doi.org/10.1016/j.appet.2017.11.093

Roodhuyzen, D. M. A., Luning, P. A., Fogliano, V., \& Steenbekkers, L. P. A. (2017). Putting together the puzzle of consumer food waste: Towards an integral perspective. Trends in Food Science \& Technology, 68, 37-50. https://doi.org/10.1016/j.tifs.2017.07.009

Röös, E., Sundberg, C., \& Hansson, P.-A. (2014). Carbon footprint of food products. In Assessment of Carbon Footprint in Different Industrial Sectors, Volume 1 (pp. 85-112). Springer.

Rosenfeld, D. L. (2020). Gender differences in vegetarian identity: How men and women construe meatless dieting. Food Quality and Preference, 81, 103859. https://doi.org/10.1016/j.foodqual.2019.103859

Schanes, K., Dobernig, K., \& Gözet, B. (2018). Food waste matters-A systematic review of household food waste practices and their policy implications. Journal of Cleaner Production, 182, 978-991. https://doi.org/10.1016/j.jclepro.2018.02.030

Schanes, K., \& Stagl, S. (2019). Food waste fighters: What motivates people to engage in food sharing? Journal of Cleaner Production, 211, 1491-1501. https://doi.org/10.1016/j.jclepro.2018.11.162

Schmidt, K., \& Matthies, E. (2018). Where to start fighting the food waste problem? Identifying most promising entry points for intervention programs to reduce household food waste and 
overconsumption of food. Resources, Conservation and Recycling, 139, 1-14.

https://doi.org/10.1016/j.resconrec.2018.07.023

Shelton, B. A., \& John, D. (1996). The Division of Household Labor. Annual Review of Sociology, 22(1), 299322. https://doi.org/10.1146/annurev.soc.22.1.299

Sorokowska, A., Marczak, M., Misiak, M., Oleszkiewicz, A., Niemczyk, A., Wróbel, M., \& Sorokowski, P. (2021). Humans tend to share food more generously than money and other objects: Preliminary evidence. European Journal of Social Psychology. https://doi.org/10.1002/ejsp.2747

Stancu, V., Haugaard, P., \& Lähteenmäki, L. (2016). Determinants of consumer food waste behaviour: Two routes to food waste. Appetite, 96, 7-17. https://doi.org/10.1016/j.appet.2015.08.025

Stefan, V., van Herpen, E., Tudoran, A. A., \& Lähteenmäki, L. (2013). Avoiding food waste by Romanian consumers: The importance of planning and shopping routines. Food Quality and Preference, 28(1), 375-381. https://doi.org/10.1016/j.foodqual.2012.11.001

The jamovi project. (2020). jamovi (Version 1.2) [Computer Software]. Retrieved from https://www.jamovi.org.

Toti, E., Di Mattia, C., \& Serafini, M. (2019). Metabolic Food Waste and Ecological Impact of Obesity in Food and Agriculture Organization World's Region. Frontiers in Nutrition, 6. https://doi.org/10.3389/fnut.2019.00126

United Nations. (2020). Goal 2: Zero Hunger. United Nations Sustainable Development. https://www.un.org/sustainabledevelopment/hunger/

van Herpen, E., van der Lans, I. A., Holthuysen, N., Nijenhuis-de Vries, M., \& Quested, T. E. (2019). Comparing wasted apples and oranges: An assessment of methods to measure household food waste. Waste Management, 88, 71-84. https://doi.org/10.1016/j.wasman.2019.03.013 van Herpen, E., van Geffen, L., Nijenhuis-de Vries, M., Holthuysen, N., van der Lans, I., \& Quested, T. (2019). A validated survey to measure household food waste. MethodsX, 6, 2767-2775. https://doi.org/10.1016/j.mex.2019.10.029 
Visschers, V. H., Wickli, N., \& Siegrist, M. (2016). Sorting out food waste behaviour: A survey on the motivators and barriers of self-reported amounts of food waste in households. Journal of Environmental Psychology, 45, 66-78. https://doi.org/10.1016/j.jenvp.2015.11.007 


\section{Supplement}

\section{Food Wasting Behaviours Questionnaire}

Instruction: Please, use the scale below to indicate how often you behave as described.

Scale: 1 - Never; 2 - Very Rarely, 3 - Rarely, 4 - Difficult to say; 5 - Occasionally; 6 - Very Frequently; 7 Always

Note: If possible, present the items in random order.

\begin{tabular}{|c|c|c|}
\hline Factor & No. & Item \\
\hline \multirow{4}{*}{$\begin{array}{l}\text { Discarding } \\
\text { unpalatable foods }\end{array}$} & 1. & I throw away food I do not like. \\
\hline & 2. & I throw away dried out food. \\
\hline & 3. & I throw away wilted food. \\
\hline & 4. & I throw away food that looks unpalatable. \\
\hline \multirow{4}{*}{ Buying as needed } & 5. & I only buy the food I need. \\
\hline & 6. & I buy small amounts of food. \\
\hline & 7. & I buy as much food as I need at any one time. \\
\hline & 8. & I avoid overshopping. \\
\hline \multirow{4}{*}{ Planning meals } & 9. & I plan meals for the next day. \\
\hline & 10. & I make a plan before shopping. \\
\hline & 11. & I try to prepare meals that I can eat the next day. \\
\hline & 12. & I make shopping lists before I go grocery shopping. \\
\hline \multirow{4}{*}{ Sharing food } & 13. & I share the food I can't eat with people I know. \\
\hline & 14. & I give away food I can't eat. \\
\hline & 15. & I give away surplus food to people who need it. \\
\hline & 16. & I pass surplus food to people who are hungry. \\
\hline \multirow{4}{*}{ Feeding animals } & 17. & I feed leftover food to my pets. \\
\hline & 18. & I feed leftover food to animals. \\
\hline & 19. & I feed animals when I have excess food. \\
\hline & 20. & I feed hungry animals with food I cannot eat. \\
\hline
\end{tabular}




\section{Table S1}

The list of items used in Study $1 b$ to establish the final version of Food Wasting Behaviours Questionnaire

\begin{tabular}{|c|c|c|c|}
\hline No. & FWBQ & Polski / Polish (original) & English \\
\hline 1 & & Chodzę na zakupy najedzonym. & I go shopping satiated. \\
\hline 2 & Sharing & $\begin{array}{l}\text { Dzielę się ze znajomymi jedzeniem, którego nie } \\
\text { mogę zjeść. }\end{array}$ & I share food I can't eat with people I know. \\
\hline 3 & & $\begin{array}{l}\text { Dzielę się z innymi jedzeniem, którego nie mogę } \\
\text { zjeść. }\end{array}$ & I share food I can't eat with others. \\
\hline 4 & & Swoje jedzenie przygotowuję w domu. & I prepare my own food at home. \\
\hline 5 & & $\begin{array}{l}\text { Jeśli jest możliwość, kupuję mniejsze opakowania z } \\
\text { jedzeniem. }\end{array}$ & If possible, I buy smaller packages of food. \\
\hline 6 & & Jeżeli owoce są zbyt dojrzałe, wyrzucam je. & If fruits are too ripe, I throw them away. \\
\hline 7 & & Kiedy się najem, kończę jedzenie i zostawiam resztki. & $\begin{array}{l}\text { When I am full, I finish eating and leave the } \\
\text { leftovers. }\end{array}$ \\
\hline 8 & Feeding & Karmię zwierzęta domowe resztkami jedzenia. & I feed leftover food to my pets. \\
\hline 9 & & Kupuję jedzenie, które się szybko psuje. & I buy food that spoils quickly. \\
\hline 10 & & Kupuję mrożone jedzenie. & I buy frozen food. \\
\hline 11 & Buying & Kupuję jedynie potrzebne produkty żywnościowe. & I only buy the food I need. \\
\hline 12 & Buying & Kupuję małe ilości jedzenia. & I buy small amounts of food. \\
\hline 13 & Buying & $\begin{array}{l}\text { Kupuję tyle jedzenia, ile potrzebuję w danym } \\
\text { momencie. }\end{array}$ & I buy as much food as I need at any one time. \\
\hline 14 & & $\begin{array}{l}\text { Kupuję warzywa i owoce, które są świeże, ale } \\
\text { brzydko wyglądają. }\end{array}$ & $\begin{array}{l}\text { I buy fruit and vegetables that are fresh but look } \\
\text { ugly. }\end{array}$ \\
\hline 15 & & Nakładam małe porcje jedzenia. & I put on small portions of food. \\
\hline 16 & & $\begin{array}{l}\text { Unikam kupowania nieznanego jedzenia, które może } \\
\text { okazać się niesmaczne. }\end{array}$ & $\begin{array}{l}\text { I avoid buying unfamiliar food which may not be } \\
\text { tasty. }\end{array}$ \\
\hline 17 & Buying & Unikam robienia zakupów na zapas. & I avoid overshopping. \\
\hline 18 & & Notuję wyrzucane jedzenie. & I make a note of the food I throw away. \\
\hline 19 & Sharing & Oddaję innym żywność, której nie mogę zjeść. & I give away food I can't eat. \\
\hline 20 & & $\begin{array}{l}\text { Planuję przyrządzenie posiłku z jedzenia, które może } \\
\text { się zepsuć. }\end{array}$ & I plan to cook a meal from food that can go bad. \\
\hline 21 & Planning & Planuję posiłki na następny dzień. & I plan meals for the next day. \\
\hline 22 & & Planuję swoje posiłki. & I plan my meals. \\
\hline
\end{tabular}




\begin{tabular}{|c|c|c|c|}
\hline No. & FWBQ & Polski / Polish (original) & English \\
\hline 23 & & Próbuję potraw w trakcie ich gotowania. & I try food while it is cooking. \\
\hline 24 & & Przechowuję resztki jedzenia w lodówce. & I store leftover food in the refrigerator. \\
\hline 25 & Planning & Przed zakupami przygotowuję plan. & I make a plan before shopping. \\
\hline 26 & & $\begin{array}{l}\text { Przeszacowuję swoją możliwość zjedzenia jedzenia, } \\
\text { kiedy nakładam je na talerz. }\end{array}$ & $\begin{array}{l}\text { I overestimate my ability to eat food when I put it on } \\
\text { my plate. }\end{array}$ \\
\hline 27 & & Przetwarzam resztki jedzenia. & I recycle leftover food. \\
\hline 28 & & $\begin{array}{l}\text { Przygotowuję przetwory z owoców, które mogą się } \\
\text { zepsuć. }\end{array}$ & I make preserves of fruit which can go bad. \\
\hline 29 & & Resztki jedzenia zjadam w pierwszej kolejności. & I eat leftovers first. \\
\hline 30 & & Robię zakupy często i kupuję małe ilości jedzenia. & I shop often and buy small amounts of food. \\
\hline 31 & & Robię zakupy zgodnie z listą zakupów. & I shop according to a shopping list. \\
\hline 32 & & $\begin{array}{l}\text { Spożywam swoje jedzenie, nawet jeśli mi nie } \\
\text { smakuje. }\end{array}$ & I eat my food, even if I don't like it. \\
\hline 33 & & $\begin{array}{l}\text { Sprawdzam, czy jedzenie nadaje się do spożycia } \\
\text { pomimo daty ważności. }\end{array}$ & I check food for expiry dates. \\
\hline 34 & & $\begin{array}{l}\text { Sprawdzam termin przydatności do spożycia przed } \\
\text { kupnem jedzenia. }\end{array}$ & I check the best-before dates before buying food. \\
\hline 35 & & $\begin{array}{l}\text { Staram się kupować tyle jedzenia, ile potrzebuję w } \\
\text { danym momencie. }\end{array}$ & I try to buy as much food as I need at any one time. \\
\hline 36 & & Staram się odpowiednio przechowywać jedzenie. & I try to store food properly. \\
\hline 37 & Planning & $\begin{array}{l}\text { Staram się przygotowywać potrawy, które mogę } \\
\text { zjeść następnego dnia. }\end{array}$ & I try to prepare meals that I can eat the next day. \\
\hline 38 & & Staram się spożywać jedzenie z umiarem. & I try to eat in moderation. \\
\hline 39 & & $\begin{array}{l}\text { Staram się wykorzystywać resztki jedzenia w } \\
\text { gotowaniu. }\end{array}$ & I try to use leftover food in cooking. \\
\hline 40 & Planning & Tworzę listy zakupów przed zakupami spożywczymi. & I make shopping lists before I go grocery shopping. \\
\hline 41 & & Tworzę dla siebie jadłospisy. & I create menus for myself. \\
\hline 42 & & Unikam kupowania mięsa. & I avoid buying meat. \\
\hline 43 & & $\begin{array}{l}\text { Ustawiam produkty w lodówce tak, aby te bliskie } \\
\text { zepsucia były z przodu. }\end{array}$ & $\begin{array}{l}\text { I arrange products in the fridge so that those close to } \\
\text { spoiling are at the front. }\end{array}$ \\
\hline 44 & & $\begin{array}{l}\text { Wyrzucam jedzenie, by zrobić miejsce na nowe } \\
\text { jedzenie. }\end{array}$ & I throw away food to make room for new food. \\
\hline 45 & & Wyrzucam jedzenie, jeśli ma skazy. & I throw food away if it has blemishes. \\
\hline
\end{tabular}




\begin{tabular}{|c|c|c|c|}
\hline No. & FWBQ & Polski / Polish (original) & English \\
\hline 46 & & $\begin{array}{l}\text { Wyrzucam jedzenie profilaktycznie, bo może się } \\
\text { zepsuć. }\end{array}$ & $\begin{array}{l}\text { I throw away food prophylactically because it might } \\
\text { spoil. }\end{array}$ \\
\hline 47 & & Wyrzucam jedzenie z nudów. & I throw away food out of boredom. \\
\hline 48 & & Wyrzucam jedzenie, jeśli straciło smak. & I throw away food if it has lost its flavour. \\
\hline 49 & & Wyrzucam jedzenie, jeżeli zostało uszkodzone. & I throw away food if it's been damaged. \\
\hline 50 & & $\begin{array}{l}\text { Wyrzucam jedzenie, kiedy nie mam pewności, że jest } \\
\text { zdatne do spożycia. }\end{array}$ & I throw away food when I'm not sure it's safe to eat. \\
\hline 51 & Discarding & Wyrzucam jedzenie, które mi nie smakuje. & I throw away food I don't like. \\
\hline 52 & & Wyrzucam jedzenie, które upadnie mi na ziemię. & I throw away food that falls on the ground. \\
\hline 53 & & $\begin{array}{l}\text { Wyrzucam jedzenie, które zbliża się do końca daty } \\
\text { ważności. }\end{array}$ & $\begin{array}{l}\text { I throw away food that is approaching its expiry } \\
\text { date. }\end{array}$ \\
\hline 54 & & $\begin{array}{l}\text { Wyrzucam jedzenie, które zostało dotknięte przez } \\
\text { owada. }\end{array}$ & $\begin{array}{l}\text { I throw away food that has been touched by an } \\
\text { insect. }\end{array}$ \\
\hline 55 & & $\begin{array}{l}\text { Wyrzucam jedzenie, które zostało napoczęte przez } \\
\text { kogoś innego. }\end{array}$ & $\begin{array}{l}\text { I throw away food that has been broached by } \\
\text { someone else. }\end{array}$ \\
\hline 56 & & $\begin{array}{l}\text { Wyrzucam jedzenie, które zostało polizane przez } \\
\text { zwierzę. }\end{array}$ & I throw away food that has been licked by an animal. \\
\hline 57 & & Wyrzucam jedzenie, na które tracę ochotę. & I throw away food that I'm losing interest in. \\
\hline 58 & & Wyrzucam jedzenie, o którym zapomniałem/am. & I throw away food that I have forgotten about. \\
\hline 59 & & $\begin{array}{l}\text { Wyrzucam jedzenie, w którym znajduje się } \\
\text { niesmaczny dodatek. }\end{array}$ & $\begin{array}{l}\text { I throw away food that has an unpalatable } \\
\text { ingredient in it. }\end{array}$ \\
\hline 60 & & Wyrzucam nadmiar zakupionego jedzenia. & I throw away excess purchased food. \\
\hline 61 & & Wyrzucam obite jedzenie. & I throw away bruised food. \\
\hline 62 & & $\begin{array}{l}\text { Wyrzucam produkty, które przekroczyły datę } \\
\text { przydatności do spożycia bez sprawdzenia ich smaku } \\
\text { i zapachu. }\end{array}$ & $\begin{array}{l}\text { I throw away food that is past its best before date } \\
\text { without checking it for taste or smell. }\end{array}$ \\
\hline 63 & & Wyrzucam przeterminowaną żywność. & I throw away expired food. \\
\hline 64 & & Wyrzucam przypalone jedzenie. & I throw away burnt food. \\
\hline 65 & & Wyrzucam resztki jedzenia po gościach. & I throw away leftover food from guests. \\
\hline 66 & Discarding & Wyrzucam wyschnięte jedzenie. & I throw away dried out food. \\
\hline 67 & Discarding & Wyrzucam zwiędnięte jedzenie. & I throw away wilted food. \\
\hline 68 & & Wyrzucam źle przygotowane potrawy. & I throw away badly prepared food. \\
\hline 69 & & Zamrażam jedzenie, którego mam za dużo. & I freeze food I have too much of \\
\hline
\end{tabular}




\begin{tabular}{|c|c|c|c|}
\hline No. & FWBQ & Polski / Polish (original) & English \\
\hline 70 & & Zapraszam bliskich na wspólne posiłki. & I invite people to share meals with me \\
\hline 71 & & Gotuję z resztek jedzenia. & I cook with leftover food. \\
\hline 72 & & Kupuję za dużo jedzenia w sklepie. & I buy too much food at the shop. \\
\hline 73 & & Kupuję bardzo duże ilości jedzenia. & I buy very large amounts of food. \\
\hline 74 & & $\begin{array}{l}\text { Kupuję nowe produkty spożywcze, które okazują się } \\
\text { być niesmaczne. }\end{array}$ & I buy new food that turns out not to be tasty. \\
\hline 75 & & Zostawiam resztki dania, które jest za duże. & I leave leftovers of a dish that is too big. \\
\hline 76 & & Przyrządzam jedzenie niepoprawnie. & I cook food incorrectly. \\
\hline 77 & & Przygotowuję zbyt dużą ilość jedzenia dla gości. & I prepare too much food for guests. \\
\hline 78 & & Robię nieprzemyślane zakupy spożywcze. & I make ill-considered grocery purchases. \\
\hline 79 & & $\begin{array}{l}\text { Wyrzucam jedzenie, które posiada niechciany przeze } \\
\text { mnie składnik. }\end{array}$ & $\begin{array}{l}\text { I throw away food that has an ingredient I don't } \\
\text { want. }\end{array}$ \\
\hline 80 & & $\begin{array}{l}\text { Wyrzucam jedzenie, kiedy nie mam miejsca w } \\
\text { lodówce. }\end{array}$ & $\begin{array}{l}\text { I throw away food when I don't have room in the } \\
\text { fridge. }\end{array}$ \\
\hline 81 & & $\begin{array}{l}\text { Wyrzucam jedzenie, kiedy nie mam pomysłu co z } \\
\text { nim zrobić. }\end{array}$ & $\begin{array}{l}\text { I throw food away when I have no idea what to do } \\
\text { with it. }\end{array}$ \\
\hline 82 & & $\begin{array}{l}\text { Wyrzucam jedzenie, kiedy nie wiem, jak je } \\
\text { przyrządzić. }\end{array}$ & I throw food away when I don't know how to cook it. \\
\hline 83 & & $\begin{array}{l}\text { Wyrzucam jedzenie z obawy, że jest } \\
\text { przeterminowane. }\end{array}$ & I throw food away for fear that it's out of date. \\
\hline 84 & & Wyrzucam jedzenie ze strachu przed zatruciem. & I throw food away for fear of poisoning it. \\
\hline 85 & & $\begin{array}{l}\text { Wyrzucam jedzenie ze względu na jego } \\
\text { nieestetyczny wygląd. }\end{array}$ & I throw away food because it looks unsightly. \\
\hline 86 & & Niewłaściwie przechowuję jedzenie w lodówce. & I don't store food properly in the fridge. \\
\hline 87 & & Wyrzucam jedzenie, które jest nieświeże. & I throw away food that is stale. \\
\hline 88 & & $\begin{array}{l}\text { Wyrzucam jedzenie, które ma nieestetyczne } \\
\text { opakowanie. }\end{array}$ & I throw away food that has unsightly packaging. \\
\hline 89 & & Wyrzucam jedzenie, które nieapetycznie pachnie. & I throw away food that smells bad. \\
\hline 90 & Discarding & Wyrzucam jedzenie, które wygląda nieapetycznie. & I throw away food that looks unpalatable. \\
\hline 91 & & Wyrzucam jedzenie, które zalega w lodówce. & I throw away food that is sitting in the fridge. \\
\hline 92 & & Wyrzucam jedzenie, które zostało uszkodzone. & I throw away food that has been damaged. \\
\hline 93 & Feeding & Karmię zwierzęta resztkami jedzenia. & I feed leftover food to animals. \\
\hline
\end{tabular}




\begin{tabular}{|c|c|c|c|}
\hline No. & FWBQ & Polski / Polish (original) & English \\
\hline 94 & & Wyrzucam potrawy, które mnie znudziły. & I throw away food that I'm bored with. \\
\hline 95 & & Robię zbyt duże zakupy. & I shop too much. \\
\hline 96 & & Karmię zwierzęta domowe resztkami jedzenia. & I feed leftover food to pets. \\
\hline 97 & Sharing & $\begin{array}{l}\text { Oddaję nadmiar jedzenia osobom, które go } \\
\text { potrzebują. }\end{array}$ & I give away surplus food to people who need it. \\
\hline 98 & & $\begin{array}{l}\text { Dzielę się jedzeniem, którego nie mogę zjeść z } \\
\text { osobami potrzebującymi. }\end{array}$ & I share food I can't eat with people who need it. \\
\hline 99 & Sharing & Przekazuję nadmiar jedzenia osobom głodnym. & I pass surplus food to people who are hungry. \\
\hline 100 & Feeding & $\begin{array}{l}\text { Jeżeli mam nadmiar jedzenia, dokarmiam nim } \\
\text { zwierzęta. }\end{array}$ & I feed animals when I have excess food. \\
\hline 101 & Feeding & $\begin{array}{l}\text { Karmię głodne zwierzęta jedzeniem, którego nie } \\
\text { mogę spożyć. }\end{array}$ & I feed hungry animals with food I can't eat. \\
\hline 102 & & Kompostuję resztki jedzenia. & I compost leftover food. \\
\hline 103 & & $\begin{array}{l}\text { Używam jedzenia, którego nie udało mi się zjeść, } \\
\text { jako nawozu. }\end{array}$ & I use food I have not managed to eat as fertiliser. \\
\hline 104 & & Przeznaczam nadmiar jedzenia na kompost. & I use surplus food for compost. \\
\hline
\end{tabular}




\section{Table S2}

Odds ratio for ordinal regression model considering Food Wasting Behaviours Questionnaire and the amount of wasted meat.

\begin{tabular}{lcccccc}
\hline & & & \multicolumn{2}{c}{$95 \% \mathrm{Cl}$} & & \\
Predictor & $B$ & $S E$ & Lower & Upper & & OR \\
\hline Discarding unpalatable foods & 0.09 & 0.02 & 0.05 & 0.12 & $<.001$ & 1.09 \\
Buying as needed & -0.07 & 0.02 & -0.12 & -0.03 & 0.002 & 0.93 \\
Planning meals & -0.03 & 0.02 & -0.08 & 0.01 & 0.174 & 0.97 \\
Sharing food & -0.03 & 0.02 & -0.07 & 0.01 & 0.185 & 0.97 \\
Feeding animals & -0.00 & 0.01 & -0.03 & 0.03 & 0.972 & 1.00 \\
Age & -0.01 & 0.01 & -0.03 & 0.02 & 0.632 & 0.99 \\
Gender & -0.40 & 0.26 & -0.93 & 0.09 & 0.123 & 0.67 \\
Vegetarian/Vegan $^{\mathrm{b}}$ & -1.44 & 0.37 & -2.23 & -0.76 & $<.001$ & 0.24 \\
\hline
\end{tabular}

Note.

a Gender variable was included as a dummy variable (0 - women, 1 - men)

${ }^{\mathrm{b}}$ Vegetarian/Vegan variable was included as a dummy variable (0 - non-veg, 1 - veg) 


\section{Table S3}

Odds ratio for ordinal regression model considering Food Wasting Behaviours Questionnaire and the amount of wasted dairy.

\begin{tabular}{|c|c|c|c|c|c|c|}
\hline \multirow[b]{2}{*}{ Predictor } & \multirow[b]{2}{*}{$B$} & \multirow[b]{2}{*}{$S E$} & \multicolumn{2}{|c|}{$95 \% \mathrm{Cl}$} & \multirow[b]{2}{*}{$p$} & \multirow[b]{2}{*}{$O R$} \\
\hline & & & Lower & Upper & & \\
\hline Discarding unpalatable foods & 0.08 & 0.02 & 0.05 & 0.11 & $<.001$ & 1.08 \\
\hline Buying as needed & -0.04 & 0.02 & -0.08 & -0.01 & 0.023 & 0.96 \\
\hline Planning meals & 0.00 & 0.02 & -0.04 & 0.04 & 0.977 & 1.00 \\
\hline Sharing food & -0.04 & 0.02 & -0.08 & -0.01 & 0.013 & 0.96 \\
\hline Feeding animals & 0.01 & 0.01 & -0.01 & 0.03 & 0.411 & 1.01 \\
\hline Age & -0.02 & 0.01 & -0.04 & 0.00 & 0.057 & 0.98 \\
\hline Gender $^{a}$ & -0.31 & 0.21 & -0.73 & 0.09 & 0.134 & 0.73 \\
\hline Vegetarian/Vegan ${ }^{b}$ & -0.45 & 0.22 & -0.89 & -0.02 & 0.042 & 0.64 \\
\hline
\end{tabular}

Note.

a Gender variable was included as a dummy variable ( 0 - women, 1 - men)

${ }^{b}$ Vegetarian/Vegan variable was included as a dummy variable (0 - non-veg, 1 - veg) 


\section{Table S4}

Odds ratio for ordinal regression model considering Food Wasting Behaviours Questionnaire and the amount of wasted bakery.

\begin{tabular}{lcccccc}
\hline & & \multicolumn{3}{c}{$95 \% \mathrm{Cl}$} & & \\
Predictor & $B$ & $S E$ & Lower & Upper & & OR \\
\hline Discarding unpalatable foods & 0.11 & 0.02 & 0.08 & 0.14 & $<.001$ & 1.12 \\
Buying as needed & -0.02 & 0.02 & -0.06 & 0.01 & 0.208 & 0.98 \\
Planning meals & -0.03 & 0.02 & -0.07 & 0.00 & 0.077 & 0.97 \\
Sharing food & -0.01 & 0.01 & -0.04 & 0.02 & 0.567 & 0.99 \\
Feeding animals & 0.01 & 0.01 & -0.01 & 0.03 & 0.359 & 1.01 \\
Age & -0.00 & 0.01 & -0.02 & 0.01 & 0.641 & 1.00 \\
Gender & -0.51 & 0.20 & -0.90 & -0.13 & 0.010 & 0.60 \\
Vegetarian/Vegan $^{\mathrm{b}}$ & -0.04 & 0.19 & -0.41 & 0.34 & 0.852 & 0.96 \\
\hline
\end{tabular}

Note.

${ }^{\text {a }}$ Gender variable was included as a dummy variable ( 0 - women, 1 - men)

${ }^{\mathrm{b}}$ Vegetarian/Vegan variable was included as a dummy variable (0 - non-veg, 1 - veg) 


\section{Table S5}

Odds ratio for ordinal regression model considering Food Wasting Behaviours Questionnaire and the amount of wasted food in general.

\begin{tabular}{lccccccc}
\hline & & \multicolumn{3}{c}{$95 \% \mathrm{Cl}$} & & \\
Predictor & $B$ & $S E$ & Lower & Upper & & & OR \\
\hline Discarding unpalatable foods & 0.12 & 0.01 & 0.10 & 0.15 & $<.001$ & 1.13 \\
Buying as needed & -0.05 & 0.02 & -0.09 & -0.02 & 0.001 & 0.95 \\
Planning meals & -0.01 & 0.02 & -0.05 & 0.02 & 0.461 & 0.99 \\
Sharing food & -0.03 & 0.01 & -0.06 & -0.00 & 0.022 & 0.97 \\
Feeding animals & 0.01 & 0.01 & -0.01 & 0.03 & 0.328 & 1.01 \\
Age & -0.01 & 0.01 & -0.03 & 0.00 & 0.104 & 0.99 \\
Gender & -0.39 & 0.18 & -0.74 & -0.05 & 0.025 & 0.67 \\
Vegetarian/Vegan $^{\mathrm{b}}$ & -0.42 & 0.18 & -0.77 & -0.07 & 0.019 & 0.66 \\
\hline
\end{tabular}

Note.

a Gender variable was included as a dummy variable (0 - women, 1 - men)

${ }^{\mathrm{b}}$ Vegetarian/Vegan variable was included as a dummy variable (0 - non-veg, 1 - veg) 


\section{Table $\mathbf{S 6}$}

Model coefficients for multiple linear regressions predicting the frequency of behaviours measured with Food Wasting Behaviours Questionnaire

\begin{tabular}{|c|c|c|c|c|c|c|c|c|c|c|c|c|c|c|c|}
\hline \multirow[b]{2}{*}{ Predictors } & \multicolumn{3}{|c|}{ Discarding unpalatable foods } & \multicolumn{3}{|c|}{ Buying as needed } & \multicolumn{3}{|c|}{ Planning meals } & \multicolumn{3}{|c|}{ Sharing food } & \multicolumn{3}{|c|}{ Feeding animals } \\
\hline & $B(S E)$ & $\beta$ & $p$ & $B(S E)$ & $\beta$ & $p$ & $B(S E)$ & $\beta$ & $p$ & $B(S E)$ & $\beta$ & $p$ & $B(S E)$ & $\beta$ & $p$ \\
\hline Intercept & $18.93(3.03)$ & & $<.001$ & $14.77(2.55)$ & & $<.001$ & $26.35(2.52)$ & & $<.001$ & $10.14(3.08)$ & & 0.001 & $7.15(3.99)$ & & 0.074 \\
\hline Gender $^{a}$ & $-0.93(0.50)$ & -0.07 & 0.064 & $-0.46(0.42)$ & -0.04 & 0.275 & $-0.95(0.41)$ & -0.09 & 0.022 & $-1.47(0.51)$ & -0.11 & 0.004 & $0.85(0.66)$ & 0.05 & 0.198 \\
\hline Age & $-0.06(0.02)$ & -0.10 & 0.013 & $-0.01(0.02)$ & -0.01 & 0.937 & $0.01(0.02)$ & 0.01 & 0.961 & $-0.10(0.02)$ & -0.16 & $<.001$ & $-0.08(0.03)$ & -0.09 & 0.013 \\
\hline Pet $^{b}$ & $-0.51(0.43)$ & -0.05 & 0.236 & $0.24(0.36)$ & 0.03 & 0.515 & $-0.41(0.36)$ & -0.05 & 0.251 & $0.68(0.44)$ & 0.06 & 0.124 & $3.20(0.57)$ & 0.22 & $<.001$ \\
\hline Veg*anc & $-1.82(0.50)$ & -0.14 & $<.001$ & $1.34(0.42)$ & 0.13 & 0.001 & $-0.17(0.41)$ & -0.02 & 0.688 & $0.05(0.50)$ & 0.01 & 0.926 & $-1.77(0.65)$ & -0.10 & 0.006 \\
\hline Main cook ${ }^{d}$ & $-0.66(0.60)$ & -0.06 & 0.252 & $0.60(0.48)$ & 0.06 & 0.212 & $0.97(0.48)$ & 0.10 & 0.042 & $0.42(0.58)$ & 0.03 & 0.468 & $0.22(0.76)$ & 0.01 & 0.774 \\
\hline Main supplye & $-0.47(0.55)$ & -0.04 & 0.384 & $-0.12(0.46)$ & -0.01 & 0.787 & $0.38(0.45)$ & 0.04 & 0.401 & $0.39(0.55)$ & 0.03 & 0.479 & $0.26(0.72)$ & 0.02 & 0.719 \\
\hline Household size & $-0.44(0.33)$ & -0.10 & 0.176 & $0.30(0.28)$ & 0.08 & 0.271 & $-0.45(0.27)$ & -0.13 & 0.100 & $0.60(0.33)$ & 0.14 & 0.069 & $1.01(0.43)$ & 0.17 & 0.018 \\
\hline BMI & $-0.05(0.09)$ & -0.05 & 0.535 & $0.12(0.07)$ & 0.12 & 0.103 & $-0.17(0.07)$ & -0.18 & 0.016 & $0.05(0.09)$ & 0.04 & 0.586 & $0.03(0.11)$ & 0.02 & 0.812 \\
\hline $\mathrm{R}^{2}$ & \multicolumn{3}{|c|}{0.041} & \multicolumn{3}{|c|}{0.023} & \multicolumn{3}{|c|}{0.040} & \multicolumn{3}{|c|}{0.055} & \multicolumn{3}{|c|}{0.109} \\
\hline $\mathrm{F}$ & \multicolumn{3}{|c|}{3.59} & \multicolumn{3}{|c|}{1.99} & \multicolumn{3}{|c|}{3.48} & \multicolumn{3}{|c|}{4.88} & \multicolumn{3}{|c|}{10.2} \\
\hline
\end{tabular}

Note.

${ }^{a}$ coded as a dummy variable (0-women, $1-$ men)

${ }^{b}$ coded as a dummy variable ( 0 - no pet, 1 - pet)

${ }^{c}$ coded as a dummy variable ( 0 - non-vegan or vegetarian, 1 - vegan or vegetarian)

${ }^{d}$ coded as a dummy variable ( 0 - not a main cook in a household, 1 - main cook)

${ }^{e}$ coded as a dummy variable (0 - not a main food supplier in a household, 1-main supplier) 